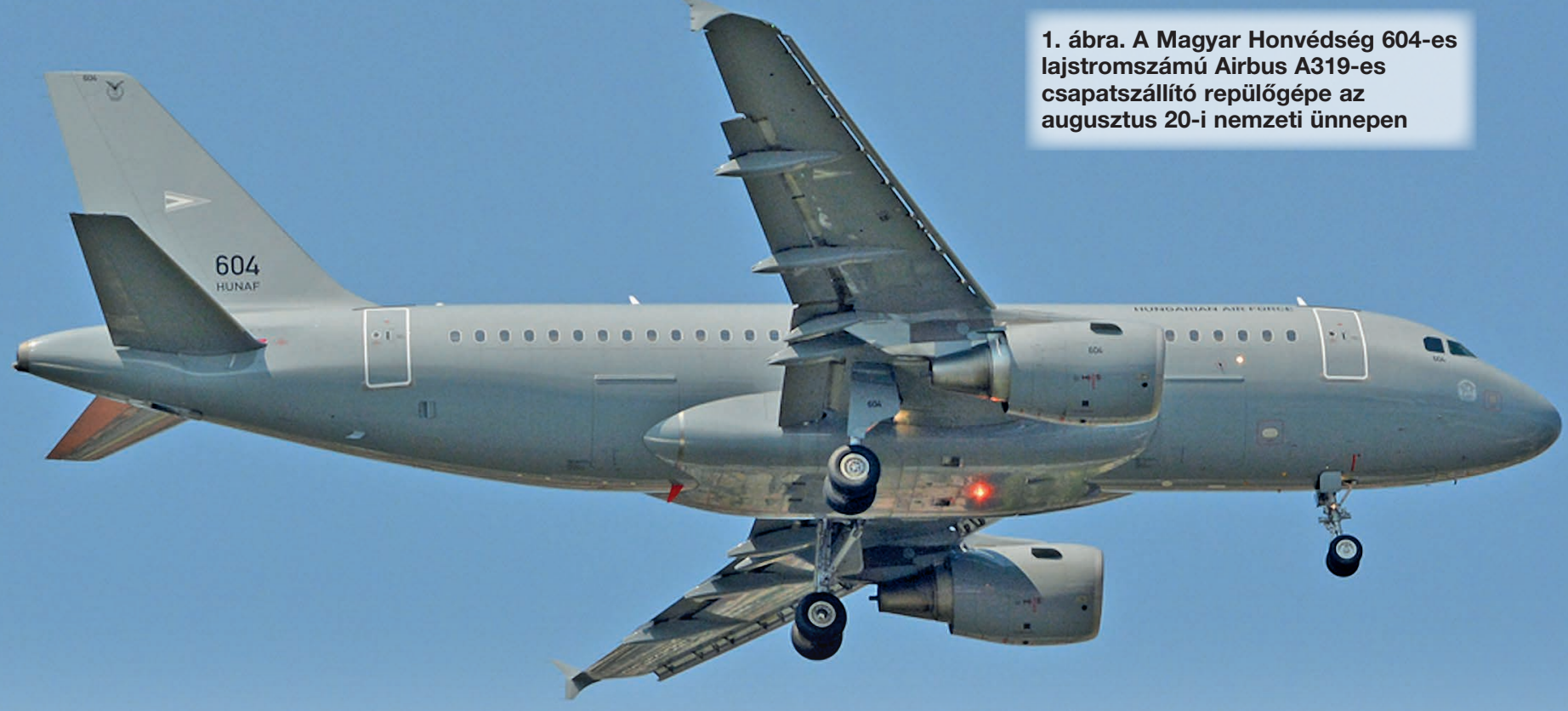

Kelecsényi István*

\title{
Airbus A319-es repülögépek a Magyar Honvédség állományában
}

\section{A SZÁLLíTÓREPÜLÉS RÖVID TÖRTÉNETE 1957-TŐL}

A polgári szállító repülőgépek katonai alkalmazásának már voltak hazánkban előzményei. A második világháború után az újjászervezett magyar légierő állományába, 1949. szeptember 9-én négy darab Liszunov Li-2-es szállító-repülőgép került Budaörsre, a 49. Önálló szállítórepülő-századba. Az 1956-os forradalom leverését követően, 1957-ben a Magyar Néphadsereg és azon belül a légierő újabb, jelentős átszervezésen ment keresztül. Kecskeméten megalakult a 86. Vegyes Repülőszázad Li-2-es, és később II-14-es szállító-repülőgépekkel. A Magyar Népköztársaság kormánya ajándékba is kapott egy II-14-es repülőgépet a Szovjetuniótól, a kiválasztott személyzetet szovjet oktatók készítették fel a gép repülésére. A repülőgép és a hajózó személyzet a kormányőrséghez, a kiszolgáló személyzet a MALÉV-hez tartozott. 1962-ben a MALEV még egy II-14-est adott át a Honvédelmi Minisztériumnak, személyzettel együtt. 1967ben megalakult a 7750/1. szállítórepülő század, amely az

ÖSSZEFOGLALÁS: 2018. január 31-én, valamint február 1-én egy-egy Airbus A319-es utasszállító repülőgép érkezett Kecskemétre, és február 2-án a hivatalos átvételt követően bemutatták a sajtónak a Hungarian Air Force feliratú NATO-szürkére festett, 604 és 605 hadrendi számmal ellátott csapatszállítókat. A csapatszállításra, teher- és személyszállíásra, illetve MEDEVAC feladatokra is alkalmas repülőgépek hadrendbe állítása jelentős képességnövekedést jelent a Magyar Honvédség számára.

KULCSSZAVAK: Magyar Honvédség, Airbus A319 utasszállitó-repülőgép, missziós feladatok, MEDEVAC
1. önálló honi légvédelmi rendészeti zászlóalj alárendeltségében működött. A szállító repülősök előtte a 86 . vegyes repülőosztály állományába tartoztak. Állományában kettő darab II-14-es repülőgép volt. 1967 decemberében érkezett meg a Szovjetuniótól beszerzett két An-24V légcsavaros gázturbinás utasszállító repülőgép. A személyzet egy részét a Szovjetunióban képezték ki, és az Antonov gyárban ismerték meg az új repülőtechnikát. Az II-14-esek személyzetét a MALÉV pilótái képezték tovább. 1968 második félévében már mindkét típust önállóan repülték a katonai pilóták. A Tupoljev Tu-134-es sugárhajtású repülőgépekre 1970-ben indult meg az átképzés, II-14-es, An24/26-os és vadászpilótákból válogatott hajózók részére. 1971. szeptember 1-től az egység, 89. önálló szállító repülőszázad néven közvetlen alárendeltségébe került az Országos Légvédelmi Parancsnokságnak. 1973. március 1-től az újonnan felállított MN Csapatrepülő Parancsnoksághoz kerültek. 1974. január 1-től Szentkirályszabadjára diszlokáltak az An-24V utasszállító repülőgépekkel, és

ABSTRACT: On 31 January 2018 and then on 1 February an Airbus A319 commercial aircraft arrived in Kecskemét, and on 2 February, after official acceptance the two transport aircraft painted in NATO-gray and marked by words Hungarian Air Force and battle order numbers 604 and 605 was shown to the media. Entering these aircraft into service that are capable of transporting troops, loads and persons and carrying out MEDEVAC tasks too means considerable increase in capability for the Hungarian Defence Force.

KEY WORDS: the Hungarian People's Army, Airbus A319 commercial aircraft, mission-oriented tasks, MEDEVAC, VIP transport

ORCID: 0000-0001-5563-3313 


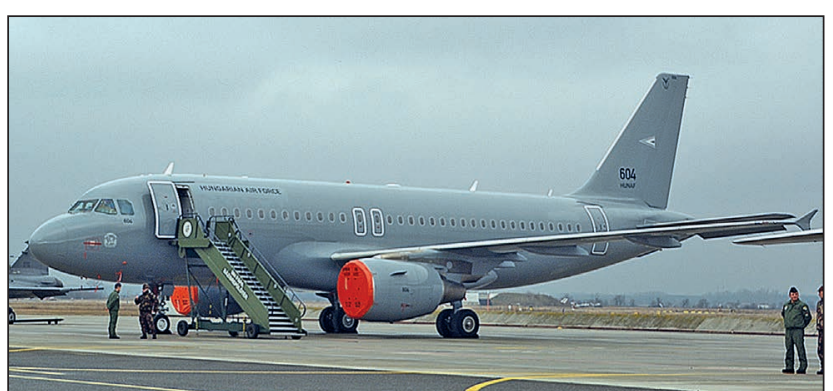

2. ábra. A Magyar Honvédség 604-es lajstromszámú Airbus A319-es csapatszállító repülőgépe a kecskeméti repülőbázison

abban az évben kaptak Zlin Z-43-as futárrepülőgépeket. A légi szállítási fegyvernem a kivont repülőgépek helyett 10 darab An-26-os közepes szállító-repülőgépet kapott, amelyek - szintén Szentkirályszabadján - az MN 1936 Önálló Szállítórepülő Század állományába tartoztak. A személyszállító feladatkörű egység 1977-ben, 93. vegyes repülőszázad néven alakult újjá. 1987. szeptembertől az egység kettő darab L-410-es és egy L-410UVP két hajtómúves könnyű szállító repülőgépet kapott. Az L-410UVP 1994 decemberéig volt hadrendben. 1990-ben az egység felvette vitéz Háry László nevét. 1991. május 1-től a századot osztály szintre fejlesztették, a Magyar Honvédség Szárazföldi Csapatok Parancsnoksága alárendeltségébe került, és a tököli repülőtér üzemeltetését is átvette. 1992-ben a kivont két An-24V szállító repülőgép helyett, azonos menynyiségű An-26-os közepes szállító repülőgépet vettek át az MH 89. Szolnok Vegyes Repülődandár állományából. 1995 decemberétől a 2. repülő és légvédelmi hadtest alárendeltségébe kerültek. A repülőosztály 2001 augusztusáig működött Tökölön, majd beolvasztották az MH 89. Vegyes Repülődandárba, és áttelepültek Szolnokra. 1991-ben az ezredet dandárrá fejlesztették, és három századának egyike An-26-os repülőgépekkel repült. (A másik kettő Mi-8T és $P$, valamint Mi-2-es helikopteres század volt.) 2004. december 1-től, a szervezeti átalakítások után, az MH 59. Szentgyörgyi Dezső Repülőbázis hadrendjébe szervezték Szolnokról a merevszárnyas repülőalegységeket. Ekkor került a bázis állományába a szállító és a kiképző repülőszázad. Az An-26-os szállítórepülő század 2005 decembe- rében települt át Kecskemétre. A Jak-52-es kiképző repülőszázad két évvel később, 2007. január 1-i hatállyal viszszakerült az MH 86. Szolnok Helikopter Bázis állományába. A 3. „Teve” szállítórepülő század feladatai között szerepel a magyar politikai és katonai vezetők bel- és külföldi szállítása. A század 2005 és 2010 között még közel féltucat An-26-os közepes szállító repülőgéppel rendelkezett, 2017-től már csak a 406-os oldalszámú üzemképes, hadra fogható.

\section{Az A319-es - A MEgFizethető ALTERnAtíva}

Az An-26-os típus már megjelenésekor sem volt optimális megoldás személyszálítására, mivel tervezése során teljesen katonai feladatkörökre optimalizálták. Az An-24-es utasszállító tervei alapján kifejlesztett, teherajtóval felszerelt szállító repülőgép 1967-ben repült először, és 1986-ig 1403 darabot gyártottak belőle.

Az An-26-os 440 km/h-s alacsony utazósebességgel repülhet, bár utastere túlnyomásos, a légcsavaros gázturbina korlátai miatt maximum 7500 méter magasságig emelkedhet, de általában 4-5000 méteren repülik. A viszonylag alacsony magasságon a repülőgép sokszor turbulens áramlatokban rázkódik, és belső tere kényelmetlen, zajos. Az utastérben füldugó használata erősen ajánlott, a kommunikáció nehézkes. A repülőgép hatótávolsága maximális üzemanyagkészlettel $2500 \mathrm{~km}$. Az An-26-os flotta elsődleges feladata élőerő- és teherszállítási feladatok, ejtőernyős ugratás, és a Nyitott Égbolt egyezménnyel összhangban légi fényképezés.

Magyarország NATO-tagsága óta a nemzetközi koalíciós feladatai megnövekedtek. A honvédség több mint ezer katonával vesz részt koalíciós és egyéb békefenntartó feladatokban. A Magyar Honvédség katonáinak szállítására, a váltások lebonyolítására az An-26-os gyakran kevésnek bizonyult. Az afganisztáni és iraki misszió már kimondottan gazdaságtalan volt, gyorsan fogyasztotta a repülési órákat, és a személyi állomány részére is indokolatlanul hosszú és megterhelő volt, akár utasként, akár személyzetként repülték.

Természeti katasztrófák, tömegbalesetek, evakuációk és egyéb humanitárius esetekben szintén jó lett volna, ha

3. ábra. Az Airbus A319-es csapatszállító repülögépböl a Magyar Honvédség két darabot szerzett be. A képen a 605-ös lajstromszámú látható Kecskeméten, az állóhelyen

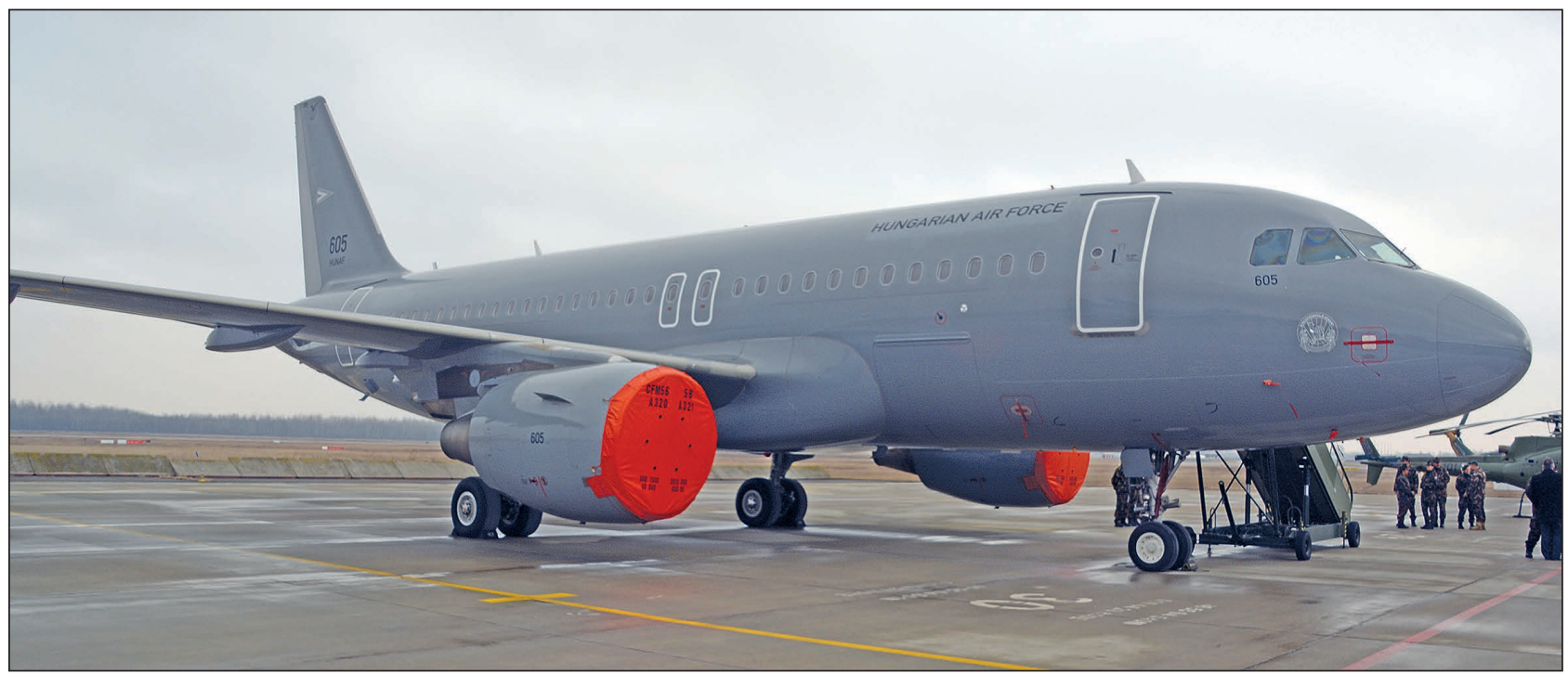




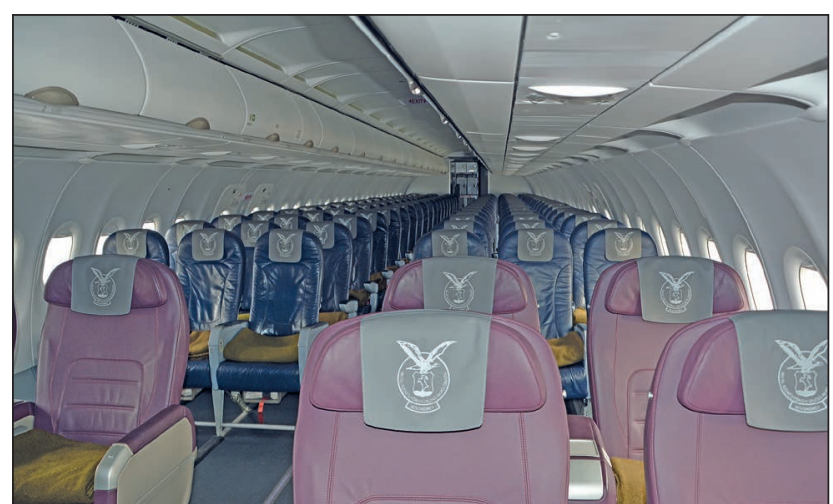

4. ábra. Az új Airbus repülőgépek utasszállító (csapatszállító) konfigurációban álltak hadrendbe, az utastér első három sorában börülésekkel (3×2), mögöttük sima bőr/szövetborítású ülésekkel $(3 \times 3)$

személyszállító/csapatszállító repülőgépekkel rendelkezett volna a honvédség.

Magyarország döntéshozói már évek óta keresték a megoldást ilyen kategóriájú repülőgépek beszerzésére. A kategóriába tartozó repülőgépek szükségességét 2006tól különböző szakcikkekben, tanulmányokban, disszertációkban lehetett olvasni. 2016-ban már több forrásból is olvasható volt, hogy az állami feladatok ellátására minden bizonnyal Airbusokat vásárolnak. A közbeszerzési eljárások alól mentességet kapott program lebonyolításához a Magyar Kormány biztosította a költségeket.

A német Air Berlin légitársaság csődje után 56 darab A319-es utasszálító repülögép került a nyomott áron a piacra. Az alacsony árat - a nagyszámú piacra került repülőgépen kívül - a típus paraméterei indokolták.

Az Airbus A319-es két hajtóműves, rövid és közepes hatótávolságú utasszállító repülőgép. Az A320-as gépcsalád egyik legrövidebb tagja. Első repülését 1995. augusztus 25-én hajtotta végre Hamburgban. 1996-ban először a Swissair állította szolgálatba. Nagyobb üzemeltető légitársaságai: az Easyjet, az American, a United és a Delta Air Lines. 2017 végéig összesen 1467 darabot építettek a típusból, több mint 50 légitársaság repüli. Nagyobb társai, az A320 és A321 típusváltozatok jóval sikeresebbek, hiszen utasszámra vetítve gazdaságosabb típusok. Az A319-est maximum 160 utasra lehetséges székekkel berendezni, és hatótávolsága 6900 km. 2014 óta az Airbus konzorcium marketingjében új ACJ319 típusjelzéssel, nagy méretű „business jet”-ként, vagyis üzleti repülőgépként árulják. Beépíthető extra üzemanyagtartállyal 11100 km-re lehet növelni hatótávolságát.

Az A319-es típust szükebb földrajzi környezetünkben Szlovákia, Csehország és Ukrajna is hadrendbe állította. A francia, német, olasz, bolgár, Európán kívül a török, örmény, brazil, maláj, thaiföldi és venezuelai légierő is rendszeresítette. A Magyar Honvédség számára kiválasztott repülőgépek közül 3604 gyártási számmal, a D-ABGM lajstromjelű első felszállása 2008. július 23-án volt. Az Air Berlin repülőgépe 2009. március 1-én átkerült a Belair lajstromába HB-IOX jelzéssel, de 2017. február 22-én viszszakapta eredeti lajstromát az Eurowings-nél.

A 3865-ös gyártási számú D-ABGS lajstromjellel 2009. március 27-én emelkedett először a levegőbe, az Air Berlin színeiben. 2012. június 6-tól az OLT Expressnél SP-IBA lajstrommal repült, majd 2012. július 17-én visszakapta a lajstromát az Air Berlinnél, és onnan került 2017. február 5-én az Eurowings-hez.

A két repülőgépet december 6-án repülték át Rómába, ahol átfestették NATO-szürkére, majd a csehországi Ostravába indultak 9H-AGN és 9-HAGM máltai felségjellel. A cseh repülőtéren „átszékezték” a repülőgépeket, és belső átalakításokat is végrehajtottak rajtuk. A honvédség két Airbus A 319-ese 2018. január 31. és február 2. között érkezett Kecskemétre.

5. ábra. A 605-ös lajstromszámú Airbus A319-es csapatszállító repülögép a levegőben, hátulnézetben. A szárnyak végein jól láthatók az áramlásjavító szárnyvégi zárólapok, amelyek üzemanyagfogyasztás-csökkenést eredményeznek

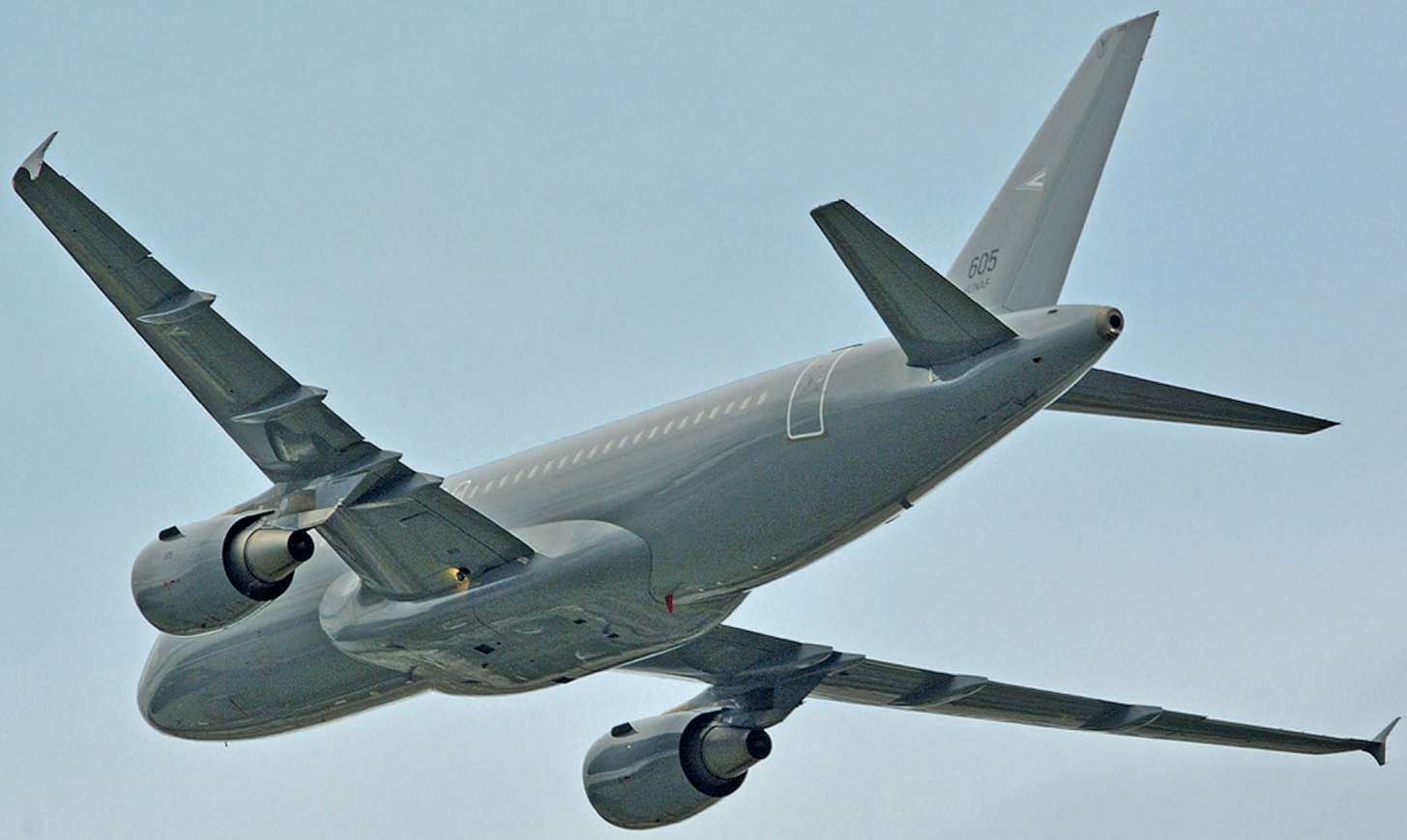




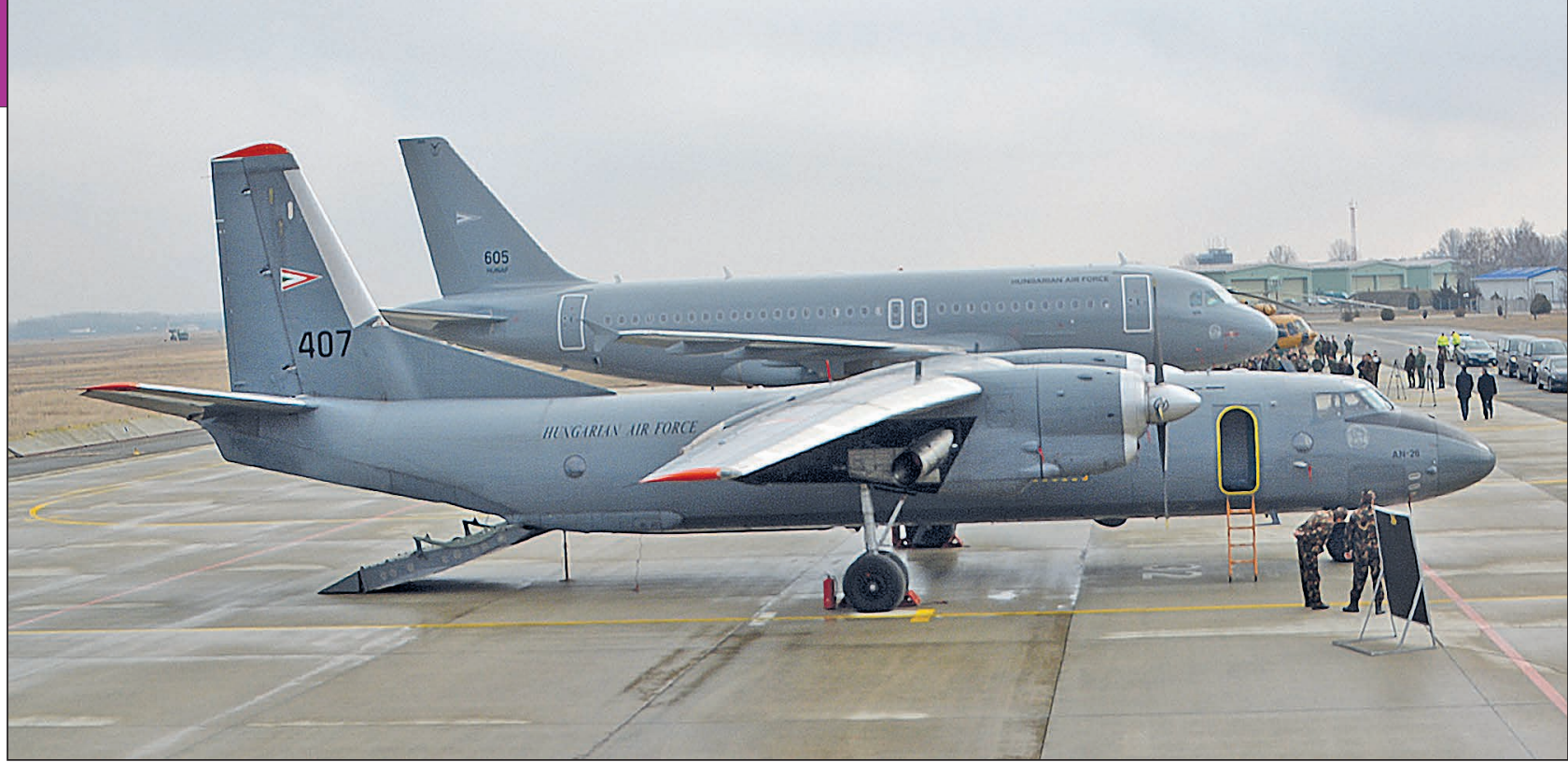

6. ábra. A múltat és a jövőt képviselő típusok egymás mellett. A korábban alkalmazott Antonov An-26-os szálítórepülőgéptípushoz képest technikai-technológiai generációváltásnak nevezhető az Airbus A-319-es repülőgéptípus megjelenése a Magyar Honvédségben

A magyar repülőgépek a sajtóbemutatón utasszállító (csapatszállító) konfigurációban álltak hadrendbe, az első három sorban bőrülésekkel $(3 \times 2)$, mögöttük sima bőr/szövetborítású ülésekkel $(3 \times 3)$. A közeljövőben a farokrészben lévő traktust sebesültszállításra is átalakíthatóvá teszik, az ehhez szolgáló kitteket szintén bemutatták a sajtótájékoztatón. Két betegszállító modult alakítottak ki, az egyikben fekvő intenzív ápolást igénylő emberek is elhelyezhetők.

A repülőgépekre a tavalyi év első felében katonai idegenbarát felismerőrendszer és kommunikációs berendezések beépítését tervezték. A hajtóműveik CFM International Jet Engine CFM56-osak, ezek üzembiztosabbak, mint a szintén használható International Aero Engines V2500-as típuscsalád.

Fontos szempont az Airbus repülőgépek önvédelmi képessége. A jelenlegi hordozható (MANPADS) légvédelmi rakéták komoly veszélyt jelentenek, típustól függően akár $8 \mathrm{~km}$ hatótávolságon belül. A legtöbb közülük infravörös „hőkövető" irányítású, bár már lézeres, és képalkotó berendezéssel ellátott változat is szerepel. A rakéták nemcsak hátulról - ahol a leforróbb a hajtómű -, hanem akár oldalról, vagy szemből is alkalmazhatók. A beszerzett repülőgépeken tervezik az önvédelmi képesség fejlesztését, amely jelentősen csökkenti a harctevékenység körzetében, veszélyes légtérben, instabil közigazgatású helyeken

7. ábra. A nagy kétáramsági fokú, gazdaságos hajtómúvek CFM International Jet Engine CFM56-os típusúak

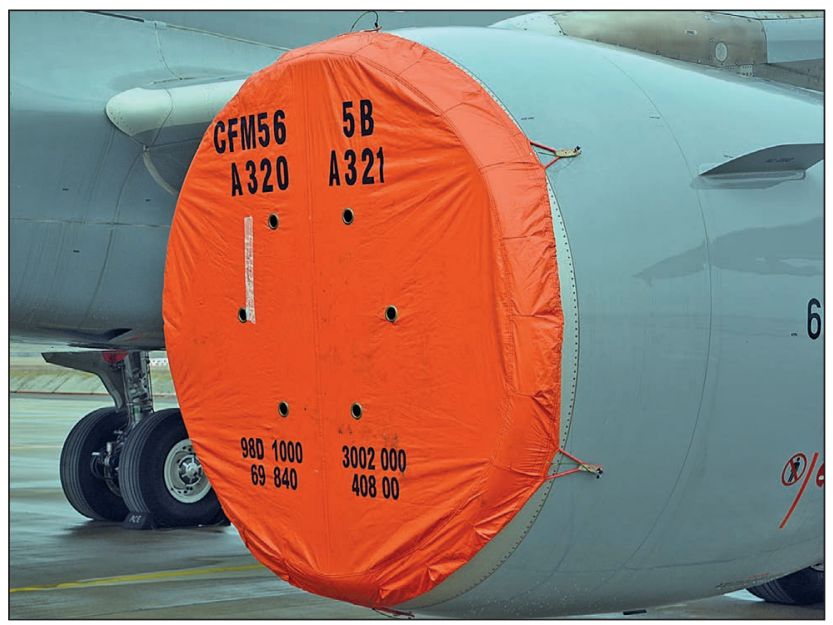

történő bevetésük kockázatát. A közeljövőben kerül ezek felszerelésére sor. Egyes források szerint az izraeli BIRD Aerosystems AeroShield (Égi pajzs) rendszere kerül beépítésre. A repülőgépek a bemutatás után, a kecskeméti bázison körülbelül két hónapig a földön tartózkodtak, ezalatt átvételi eljárásokra került sor. A műszaki személyzet a loadmasterek (rakománykezelők), az utaskísérők és a hajózók is átképzésen, képzésen vettek részt. Első pilótái kereskedelmi hajózók voltak. A pilóták típusátképzése Csehországban, Prágában történik, de az első hajózók a franciaországi Airbus központban, Toulousban is kaptak oktatást. Alapvetően az An-26-os flotta pilótái kapnak lehetőséget, de a Gripen hajózók is jelentkezhettek típus-átképzésre. Az NFTC utolsó résztvevői közül két fő már eleve szállítórepülőgép-vezetői képzésre utazik ki.

2018. április 4-én a 605-ös hadrendi számú A319-es a levegőbe emelkedett. A nyolc-kilencéves repülőgépek nem idősek, hiszen az A320-asnál a gyártó a tervezéskor 60000 repült órában, vagy 25 évben határozta meg az üzemidőt, és ennek a hosszabbítására vonatkozóan az Airbus végez fáradásos vizsgálatot. Tény, hogy jelenleg repül még a DAIPA MSN069 jelzésű A320-as a Lufthansánál, amely 28,5 éves, több mint 70000 órát töltött a levegőben, és legalább 55000 alkalommal szállt le. Az A319-esekre a honvédség kezdetben 1500-1800 éves repült órával számol,

8. ábra. A pilótafülke. A típus múszerezettsége és automatizáltsága, illetve a kijelzők megfelelnek a 21. század kihívásainak

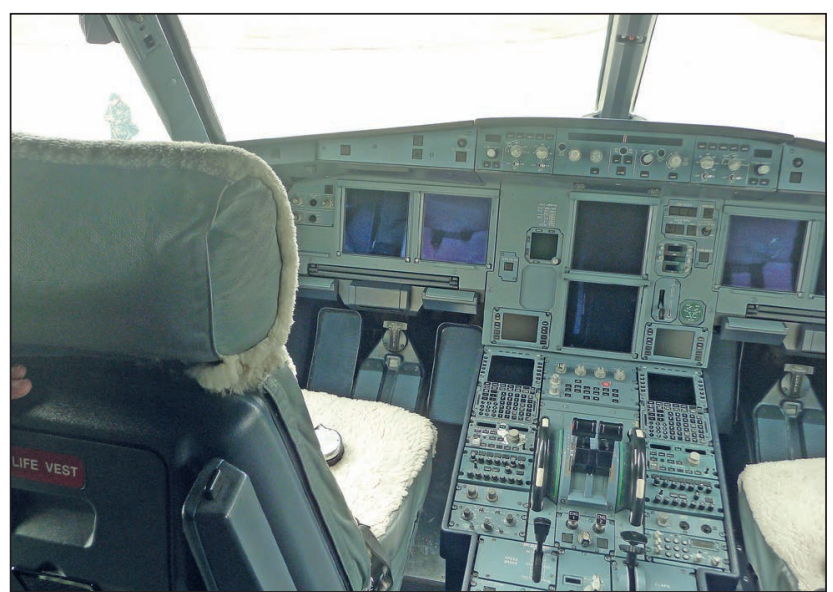




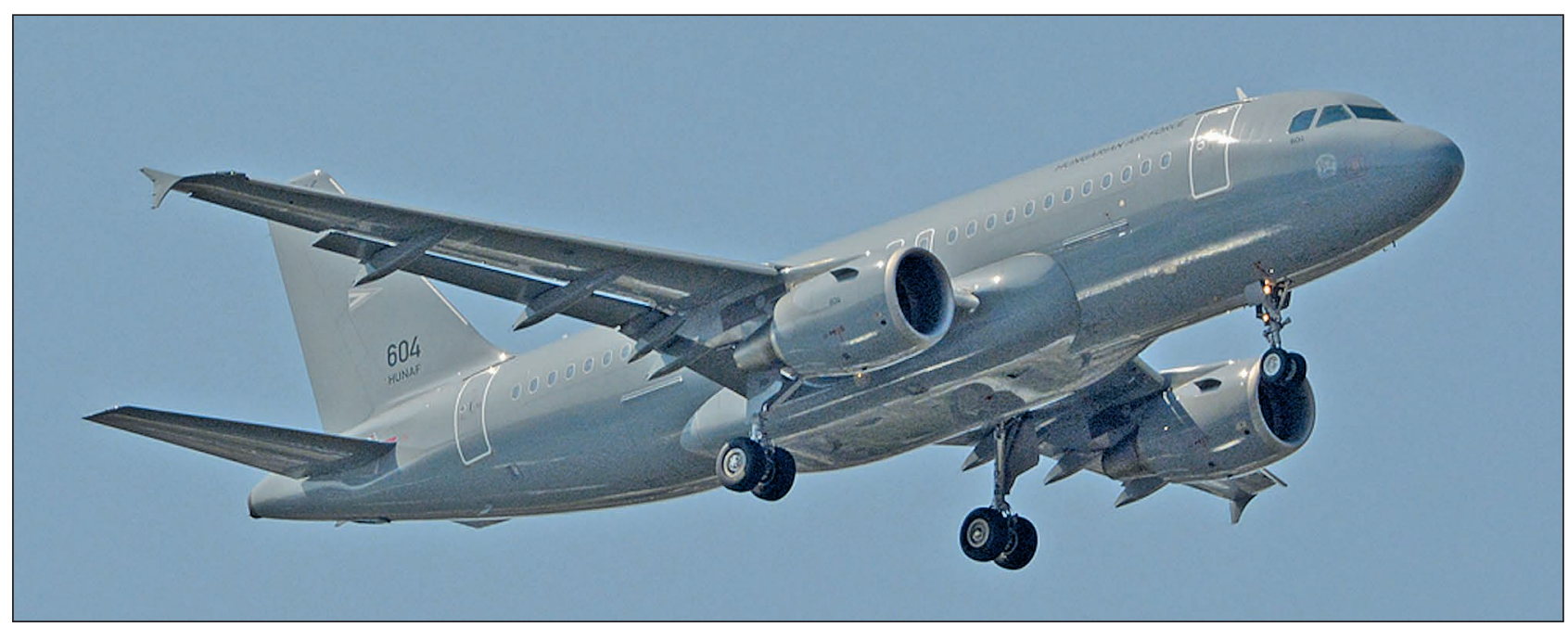

9. ábra. A 604-es lajstromszámú Airbus A319-es csapatszálító repülögép a levegőben, nyitott futóművel

így legalább másfél évtizedig alkalmazhatók. A műszakiak szakszolgálati engedélyének megszerzéséig az Aeroplex munkatársai szolgálják ki, és ellenőrzik a gépeket. A nem napi szintű javításokat, karbantartásokat, pedig mindig a cég ferihegyi hangárjában fogják elvégezni. 2018. május 17-től megkezdődtek a rendszeres kiképzési repülések, és május 24-én az első éjszakai repülés is megtörtént. $A z$ A319-esek általában CAMEL-1, CAMEL-2 hívójellel repülnek. Az első repülések különböző alapfokú manőverekből és iskolakörökből álltak, elsősorban a kecskeméti repülőbázishoz közeli légtereket használták. Júniustól a 604-es már Ljubjana, Köln és Luxemburg repülőterein is tiszteletét tette, a 605-ös pedig a fentieken kívül, már a légi haderőnem vezérkarát és pilótákat vitt a svédországi Visdel lőtérre, valamint Prágában, Brüsszelben és Pristinában is járt. Júliusban és augusztusban a 604-es Airbus Linköping, Ramstein, Köln, Bonn, Szkopje, Bydgoszcz, Poznan, Krakkó, Varsó és Zágráb repülőterein fordult meg, a 605-ös többek között Geilenkirchen, Bukarest, Szarajevó, Caslav, Kassa, Tel-Aviv, Ciprus és Prága úti célokra is repült. A repülések nagy része útvonalrepülés volt, de például Pristinába az MH KFOR Kontingens 19. váltása - amelynek gerincét az MH 5. Bocskai István Lövészdandár katonái adják - repült ki. A beszerzett A319-es csapatszállító repülőgépek rendeltetésükben nem térnek el az An-26-os szállító repülőgépektől. A különbség az, hogy az „Ancsa” a lenyitható hátsó rámpa segítségével teherszállító repülő-

10. ábra. Az A319 törzsorr részének oldalára felfestették a „Teve" szállítórepülö-század jelvényét

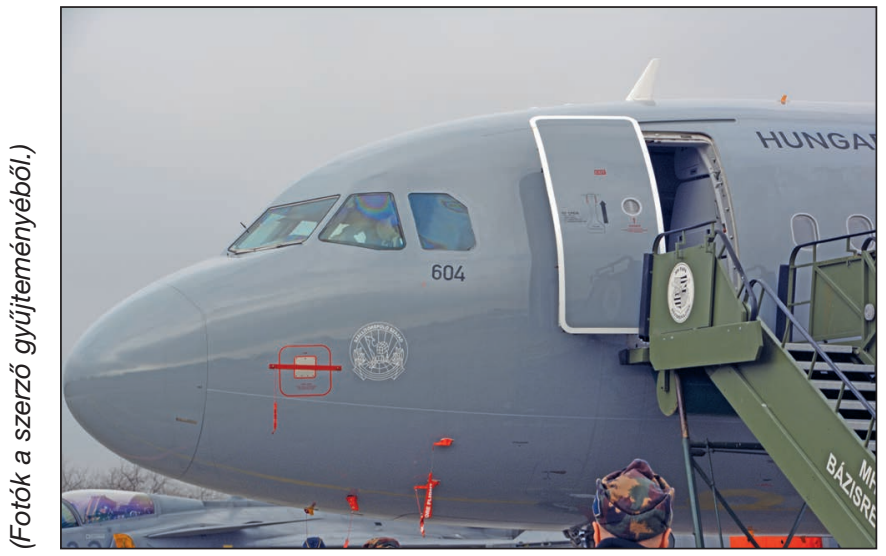

gépként sokkal könnyebben alkalmazható, mint a nagy oldalajtók nélküli A319-es. Az Airbus viszont személyszállító kapacitása miatt, jóval több katonát tud gyorsabban szállítani, hiszen az An-26-os csak kétoldali, egymással szembeni üléssorral rendelkezik, a törzs teljes hosszában a középrész kihasználatlan, valamint sebessége, a repülési magassága, és a hatótávolsága is kevesebb. Az An-26-os rámpás teherszálító képességét azonban az Airbus nem pótolja. A Magyar Honvédség ezért 2019-től 75 milliárd forintot különített el „rámpás” csapatszállító repülőgépek beszerzésére.

\section{ForRÁsOK}

http://www.airbus.com/aircraft/passenger-aircraft/ a320-family/a319ceo.html [2018.09.07];

http://airportal.hu/ilyen-lesz-magyar-legiero-airbus-a319ese/ [2018.09.07];

http://airportal.hu/bemutatkozott-magyar-honvedsegairbus-a319-es-repulogepe/ [2018.09.07];

http://www.kormany.hu/hu/honvedelmi-miniszterium/ fotok/megerkezett-a-kecskemeti-bazisra-a-ket-airbusa-319-es-csapatszallito-katonai-repulogep [2018.09.07];

https://honvedelem.hu/cikk/108500_jelentos_

koltsegmegtakaritast_eredmenyeznek_az_uj_ repulogepek [2018.09.07];

http://iho.hu/hir/kell-kormanygep-tobbfunkcios-szallitomeginkabb-180202 [2018.09.07];

http://kameraaltal.blog.hu/2018/02/02/airbus_statikus_es_ tipus_bemutato [2018.09.07];

Orosz Zoltán altábornagy: A Magyar Honvédség szállítórepülő és helikopter alegységek alkalmazási lehetőségei a NATO szövetségi rendszerében. Doktori $(\mathrm{PhD})$ értekezés;

Orosz Zoltán altábornagy: Szállítórepülők alkalmazásának kérdései a Magyar Honvédség missziós feladatrendszerében (Repüléstudományi Konferencia Szolnok 2009);

Orosz Zoltán altábornagy: Helikopterek és szállítórepülők - adalékok a légi szállítás alternatíváihoz, alkalmazási lehetőségeihez és elveihez;

Turcsányi Károly - Hegedűs Ernő: A nagy távolságú (stratégiai) légi szállítás perspektivikus kérdései I-II. rész. Katonai Logisztika 2013. évi 1. sz.;

Szarvas László ezredes: A Magyar Honvédség stratégiai szállítási lehetőségei, a ma és a jövő kihívásai. 